\title{
OBITUARY
}

\section{Marcos Di Bernardo (1963-2006)}

\section{Axel Kwet}

Department of Zoology, Staatliches Museum für Naturkunde Stuttgart, Germany

The herpetological community in Brazil and worldwide was shocked when the sad news had spread that Marcos Di Bernardo had lost his struggle against a malignant melanoma. This aggressive skin cancer first emerged at the beginning of 2004, as a consequence of a benign neoplasm, and quickly enlarged subsequently. On the $16^{\text {th }}$ of June 2006, Marcos passed away at the age of only 42. His early death abruptly put an end to his flourishing studies on the South Brazilian herpetofauna and his successful work as a professor of Zoology at the Pontifícia Universidade Católica do Rio Grande do Sul (PUCRS) in Porto Alegre, Rio Grande do Sul.

Marcos Di Bernardo was born on the $4^{\text {th }}$ of November 1963 in Bento Gonçalves, Rio Grande do Sul, where he spent his childhood and school time. Already as adolescent, Marcos was extremely interested in nature and biological sciences, and so in 1981 he moved to the capital of Rio Grande do Sul, Porto Alegre, in order to study biology at the PUCRS University. Throughout his time as a student at the "Instituto de Biociêncies” Marcos profited from lectures and courses by Professor Thales de Lema, his teacher, later colleague and personal friend. After completing in 1985, Marcos was employed as scientific assistant in the Herpetological Laboratory of the associated Museu de Ciências da PUCRS (MCP). In 1991, Marcos Di Bernardo received the master's degree from PUCRS University for his thesis on xenodontine colubrids and the revalidation of the snake genus Echinanthera, under the supervision of Thales de Lema. Between 1994 and 1998 Marcos pursued his studies on the natural history of a snake community of the southeastern margin of the Araucarian plateau ("Planalto das Araucárias”) in Rio Grande do
Sul. These studies were part of his doctoral research project at UNESP University, São Paulo (Universidade Estadual Paulista, Campus de Rio Claro). During these field studies under the supervision of Professor Ivan Sazima, I had the great privilege to get to know Marcos as an excellent field researcher, outstanding professor and, first of all, as an extremely candid, understanding and sociable friend. Our first personal meeting was in October 1995, when I first came to Brazil, in order to study anurans in Rio Grande do Sul. We were lucky be able to work together in the same nature reserve (CPCN Pró-Mata), and after resolving our initial language problems (when it turned out that my Portuguese and his German knowledge were not sufficient), we spent wonderful and fruitful years of collaborating, working and publishing together.

After completing his doctoral thesis in 1998, Marcos continued with his research activities in southern Brazil, mainly focussing on taxonomical and ecological issues with a special emphasis on snakes but also on anurans. Yet, his interests always covered a wide spectrum of herpetological questions. During this time, the herpetological collection of the Museu de Ciências da PUCRS strongly increased; today this collection may comprise around 27.000 reptile and amphibian specimens. In 2001, Marcos was employed as adjunct assistant professor by the PUCRS University in order to teach vertebrate zoology and biodiversity studies. I was greatly honoured to be invited as a guest professor in one of his first courses. During the short time span remaining until his early death, Marcos supervised more than 20 students, not less than 13 master's and nine doctoral theses! This astonishing number highlights his remarkable reputation among 
students and colleagues alike that Marcos was well liked by his students, and consequently he was honoured and awarded several times for his successful work as professor of Zoology. Marcos was a very social, patient and fair teacher, and a liberal-minded, cheerful scientist. In his short career, Marcos has published more than 60 scientific articles in journals and books and more than 75 congress abstracts. Out of these contributions, many papers were published in collaboration with colleagues from nonBrazilian states demonstrating his broad, international background. Marcos was member in the editorial board of Salamandra, the organ of the German Herpetological Society (DGHT) and, as an example, he collaborated with Raúl Maneyro from Uruguay, John Measey from England, and Mirco Solé from Germany. I personally had the chance to collaborate with him in twelve scientific contributions as well as in 15 congress abstracts. In 1999, we described a new frog species from Pró-Mata reserve, Elachistocleis erythrogaster, and our trilingual field guide on the anuran fauna of this region appeared published in the same year. In 2002 and 2004, respectively, a field project in the Candiota region in southern Rio Grande do Sul yielded in the form of two book chapters. But unfortunately our wish of completing a field guide on the reptiles of Pró-Mata and of describing a new hylid species in the genus Trachycephalus will now remain unfulfilled. The description of Melanophryniscus admirabilis, a new and really spectacular toadlet, described by him and two colleagues, was published in May 2006, only a few days before his death.

On the $5^{\text {th }}$ of November 1995, Marcos got married to Silvia Rodrigues Machado, and their daughter, Camila Di Bernardo, was born on the $9^{\text {th }}$ of April 1999. But fate has been unkind to this small family and the tragedy began when in July 2002 Silvia suddenly passed away, due to a cerebral aneurysm. The shock was even greater as Marcos was completely unprepared for this terrible news. The cousin of Silvia and godmother of Camila, Carla Nogueira, was a great support in those hard times. Carla carefully assumed the education of Camila and looked after the widower Marcos. In 2005 Marcos and Carla got married in private. When we met for the last time in January of this year, I noticed that Marcos felt secure and happy in his new family, and that he spent the remaining time contentedly with his wife and daughter. Those of us, who knew Marcos, this truly admirable personality, will miss his enthusiasm and his presence in our lives.

\section{Selected References}

Aguiar, L. F. S. and M. DI BERNARDO. 2004. Diet and feeding behavior of Helicops infrataeniatus (Serpentes, Colubridae, Xenodontinae) in southern Brazil. Studies on Neotropical Fauna and Environment 39: 714.

Aguiar, L. F. S. and M. DI BERNARDO. 2005. Reproduction of the water snake Helicops infrataeniatus Jan, 1865 (Colubridae) in southern Brazil. AmphibiaReptilia 26: 527-533.

Balestrin, R. L. and M. DI BERNARDO. Reproductive biology of Atractus reticulatus (Boulenger, 1885) (Serpentes - Colubridae) in Southern Brazil. Herpetological Journal 15: 195-199.

DI BERNARDO, M. 1992. Revalidation of the genus Echinanthera Cope, 1894, and its conceptual amplification (Serpentes, Colubridae). Comunicações do Museu de Ciências e Tecnologia da PUCRS, Série Zoologia 5: 225-256.

DI BERNARDO, M. 1994. Uma nova espécie de Echinanthera Cope, 1894 (Serpentes, Colubridae) do nordeste do Brasil. Biociências 2: 75-81.

DI BERNARDO, M. 1996. A new species of the Neotropical snake genus Echinanthera Cope, 1894 from Southeastern Brazil (Serpentes, Colubridae). The Snake 27: 120-126.

DI BERNARDO, M. and T. Lema. 1986. O gêenero Rhadinaea Cope, 1863 no Brasil Meridional. II. Rhadinaea persimilis (Cope, 1869) (Serpentes, Colubridae). Acta Biologica Leopoldensia 8: 101-122.

DI BERNARDO, M. and T. Lema. 1987. O gênero Rhadinaea Cope, 1863 no Brasil Meridional. I. Rhadinaea poecilopogon Cope, 1863 (Serpentes, Colubridae). Acta Biologica Leopoldensia 9: 203-224.

DI BERNARDO, M. and T. Lema. 1988. O gênero Rhadinaea Cope, 1863 no Brasil Meridional. III. Rhadinaea 
affinis (Günther, 1858) (Serpentes, Colubridae). Acta Biologica Leopoldensia 10: 223-252.

DI BERNARDO, M. and T. Lema. 1991. O gênero Rhadinaea Cope, 1863 no Brasil Meridional. IV. Rhadinaea bilineata (Fischer, 1885) (Serpentes, Colubridae). Acta Biologica Leopoldensia 12: 359-392.

Franco, F. L., E. L. Salomão, M. B. Martins, M. DI BERNARDO, M. Meneghel, and S. Carreira. 2001. New records of Calamodontophis paucidens (Serpentes, Colubridae, Xenodontinae) from Brazil and Uruguay. Cuadernos de Herpetología 14: 155-159.

Giraudo, A. R., G. A. Couturier and M. DI BERNARDO. 1996. Echinanthera cyanopleura (Cope, 1885), a new record for the ophidiofauna of Argentina (Serpentes: Colubridae). Cuadernos de Herpetología 10: 72.

Kwet, A. and M. DI BERNARDO. 1999. Elachistocleis erythrogaster, a new microhylid species from Rio Grande do Sul, Brazil. Studies on Neotropical Fauna and Environment 33 7-18.

Kwet, A. and M. DI BERNARDO. 2001. Das Araukarienplateau von Rio Grande do Sul, Brasilien, und seine Herpetofauna. Teil 4: Die Nattern (Colubriden) der offenen Camposregion. das Aquarium 388: 61-68.

Kwet, A. and M. DI BERNARDO. 2001. Das Araukarienplateau von Rio Grande do Sul, Brasilien, und seine Herpetofauna. Teil 5: Die Nattern (Colubriden) des Araukarienwaldes. das Aquari.um 389: 65-72.

Kwet, A. and M. DI BERNARDO, and M. B. Martins. 2001. Das Araukarienplateau von Rio Grande do Sul, Brasilien, und seine Herpetofauna. Teil 6: Die Giftschlangen und Echsen des Plateaus. das Aquarium 390: 61-69.

Kwet, A., M. DI BERNARDO and P. C. A. Garcia. 2001. The taxonomic status of Leptodactylus geminus Barrio, 1973. Journal of Herpetology 35: 56-62.

Maciel, A. P., M. DI BERNARDO, S. M. Hartz, Oliveira, R. B. and G. M. F. Pontes. 2003. Seasonal and daily activity patterns of Liophis poecilogyrus (Serpentes, Colubridae) on the north coast of Rio Grande do Sul, Brazil. Amphibia-Reptilia 24: 189-200.

Measey, G. J. and M. DI BERNARDO. 2003. Estimating juvenile abundance in a population of the semi-aquatic caecilian, Chthonerpeton indistinctum (Amphibia: Gymnophiona: Typhlonectidae), in southern Brazil. Journal of Herpetology 37: 371-373.

Melchiors, Janaíne, M. DI BERNARDO, G. M. F. Pontes, R. B. Oliveira, M. Sole and A. Kwet. 2004. Reprodução de Pseudis minuta (Anura: Hylidae) no sul do Brasil. Phyllomedusa 3: 61-68.

Oliveira, R. B., M. DI BERNARDO, G. M. F. Pontes, and A. P. Krause. 2001. Dieta e comportamento alimentar da cobra-nariguda, Lystrophis dorbignyi (Duméril, Bibron \& Duméril, 1854), no Litoral Norte do Rio Grande do Sul, Brasil. Cuadernos de Herpetología 14: 117-122.

Pontes, G. M. F., and M. DI BERNARDO. 1988. Registros sobre aspectos reprodutivos de serpentes ovíparas neotropicais (Serpentes: Colubridae e Elapidae). Comunicações do Museu de Ciências e Tecnologia da PUCRS 1: 123-149.

Ruffato, R., M. DI BERNARDO and G. F. Maschio. 2003. Dieta de Thamnodynastes strigatus (Serpentes, Colubridae) no sul do Brasil. Phyllomedusa 2: 27-34.

Santos, M. C. and M. DI BERNARDO. 2001. Human envenomation by an aglyphous colubrid snake. Liophis miliaris (Linnaeus, 1758). Cuadernos de Herpetología 14: 153-154.

Sazima, I. and M. DI BERNARDO. 1991. Albinismo em serpentes neotropicais. Memórias do Instituto Butantan 53: 167-173.

Thomas, R. A., M. DI BERNARDO and H. Grillitsch. 2001. Philodryas pallidus Werner, 1926: a synonym of the colubrid snake Liopholidophis varius (Fischer, 1884) from Madagascar. Journal of Herpetology 35: 120-122. 